\author{
Aleksander Madyda \\ Uniwersytet Mikołaja Kopernika w Toruniu \\ amadyda@umk.pl \\ ORCID: 0000-0001-6836-9152
}

\title{
Etnografia mistyczna
}

\section{Mystical ethnography}

Adriana Świątek, Huculskie peregrynacje weselne.

Obrzęd weselny jako widowisko kulturowe, Instytut Teatralny im. Zbigniewa Raszewskiego, Akademia Sztuk Teatralnych im. Stanisława Wyspiańskiego, Warszawa-Kraków 2020.

DOI: $10.12775 /$ LL.4.2021.010 | CC BY-ND 4.0

Obok dzieła naukowego Adriany Świątek trudno przejść obojętnie. Jest to bowiem owoc wieloletnich (2011-2017) systematycznych badań terenowych, prowadzonych na zachodniej Ukrainie, których celem było stworzenie monograficznego ujęcia współczesnego huculskiego obrzędu weselnego. Autorka dokonywała swych obserwacji na obszarze pięciu miejscowości położonych w centrum Huculszczyzny, czyli na historycznym Pokuciu, w dzisiejszym rejonie wierchowińskim obwodu iwano-frankiwskiego; były to: Bystrzec, Wierchowina (dawniej: Żabie), Ilci, Zamahora i Hryniawa. Rezultatem tych badań jest imponująca zarówno rozmiarami, jak i szczegółowością oraz wieloaspektowością spojrzenia praca, którą na pierwszy rzut oka należy uznać za godną umieszczenia w szeregu najwybitniejszych monografii kultury huculskiej, z czterotomową Huculszczyzna Wołodymyra Szuchewycza na czele. Oczywiście recenzowana publikacja nie rości sobie pretensji do przedstawienia całej kultury współczesnych Hucułów, jednakże dokładność naukowego opisu i dokumentacji przedmiotu badania narzuca nieodparte skojarzenia z najlepszą polską i ukraińską tradycją etnograficzną. 
Autorka nadała swemu dziełu bardzo przejrzysty układ: monografia zaczyna się od dość osobistego wprowadzenia, zatytułowanego literacko Wejście na huculski płaj, na które składają się charakterystyka obszaru badań i informacje na temat kompozycji tomu, trzon zaś monografii stanowią trzy części poświęcone kolejno: dokładnej prezentacji dotychczasowego stanu badań oraz zarysowaniu własnego stanowiska metodologicznego, następnie - drobiazgowemu opisowi wyodrębnionych w toku własnych badań trzech wariantów współczesnego obrzędu weselnego w całej ich skomplikowanej strukturze, wreszcie - dokumentacji ikonograficznej w postaci atlasu kostiumów i rekwizytów huculskiego widowiska weselnego. Książkę wieńczą trzy aneksy, z których dwa zawierają przekłady i streszczenia fragmentów nie znanych w Polsce szerzej opowiadań ludowych autorstwa Petra Szekeryka-Donykiwa pt. Dido Iwańczyk, dotyczących huculskiego wesela, a mających, zdaniem autorki, status źródła etnograficznego, trzeci zaś aneks zawiera zestawienie sygnatur materiałów fotograficznych, filmowych i dźwiękowych. Niezbędne dopełnienie tomu stanowią obszerna bibliografia oraz indeks nazwisk i miejscowości.

Niekwestionowaną wartością omawianej pracy jest również jej interdyscyplinarność, bowiem ambicją autorki było stworzenie dzieła naukowego nie tyle wyłącznie opisowego, a więc li tylko etnograficznego, ile przynoszącego pogłębiony obraz interesującego ją fenomenu kulturowego, zatem uwzględniającego również punkty widzenia innych dyscyplin nauki: antropologii kultury i teatrologii. Zewnętrznym przejawem takiego podejścia jest programowo dwuaspektowa słowna i ikonograficzna (fotografia i film) - charakterystyka badanego zjawiska kulturowego, gdyż, jak chce autorka, słowny opis „zawsze będzie niepełny, fragmentaryczny, obarczony nieuniknionym niedopowiedzeniem” (s. 79). W intencji autorki bogate materiały ikonograficzne (stanowiące, trzeba przyznać, bardzo atrakcyjny wizualnie wymiar monografii) nie pełnią tu wobec narracji słownej funkcji jedynie podrzędnej, tj. ilustracyjnej, lecz stanowią autonomiczny, poznawczo-estetyczny sposób ujęcia tematu.

Swój cel badawczy określiła Świątek jako stworzenie antropologicznej monografii współczesnego huculskiego obrzędu weselnego, rozpatrywanego w perspektywie widowiska kulturowego, przy czym badaczka usytuowała zaprezentowaną w tomie tożsamość metodologiczną w obrębie tzw. antropologii doświadczenia. Zgodnie z tym paradygmatem eksploracyjne doświadczenie terenowe autorka traktuje - analogicznie do przedmiotu swych badań - jako obrzęd przejścia, zmieniający wewnętrznie badacza. Innymi słowy, chodzi tu o stary dylemat etnologiczny: jak zachować właściwe proporcje między podejściem ethic i emic. Co ciekawe i zarazem znamienne dla zawartych w monografii wywodów, jej autorka opowiada się jednoznacznie po stronie postawy emic, jednocześnie wręcz deprecjonując ujęcie ethic. Jak pisze:

Świadomie zrezygnowałam z ankiety [...]. Antropolog widowisk może oczywiście tworzyć kwestionariusze, wpisywać w rubryki odpowiedzi „informatorów” (jak antropologia i etnografia często określa swoich bo- 
haterów, pozbawiając ich w pewnym sensie podmiotowości) i formułować wnioski na podstawie obserwacji, zestawień i porównań. Konsekwencją takiego podejścia jest jednak zazwyczaj pominięcie tego, co w antropologii, a w antropologii widowisk szczególnie, najistotniejsze i najcenniejsze: żywego Człowieka. Czytamy w szkicu z zakresu antropologii doświadczenia Victora Turnera: „Oczywiście wiele można policzyć, zmierzyć i poddać syntetycznej analizie. Jednak każde ludzkie działanie przepojone jest znaczeniem, a znaczenie trudno jest mierzyć, aczkolwiek często można je uchwycić”. W takiej perspektywie „doświadczenie terenowe” jawi się jako próba zbudowania międzyludzkiej interakcji. To początkowo układ Obserwator-Informator, który pogłębia się i w określonych okolicznościach przemienia Obserwatora w Uczestnika, a Informatora w Przewodnika (s. 78).

Nieprzypadkowo autorka używa tu wielkich liter, gdyż sygnalizują one jej wyraźnie emocjonalny stosunek do przedmiotu badań, czego liczne dowody znajdujemy $\mathrm{w}$ różnych innych miejscach monografii. To zaś sprawia, że o ile wartość omawianego opracowania jako dokumentu etnograficznego jest niezaprzeczalna, o tyle naukowość zaprezentowanego w nim dyskursu zaczyna budzić niejakie wątpliwości.

Już sam wybór narracji w pierwszej osobie liczby pojedynczej bardzo utrudnia (jeżeli w ogóle nie uniemożliwia) zachowanie dystansu do przedmiotu rozważań, który to dystans jest, jak to ciągle jeszcze ogólnie się przyjmuje, pożądany czy wręcz wymagany w pracach naukowych. Przykładem wspomnianej nietypowej praktyki Świątek jest fragment pierwszej części jej pracy:

W roku 2015 spisałam pierwszą wersje „opowieści o huculskim obrzędzie weselnym”. Uznałam, że powinna ona zostać zapisana na Huculszczyźnie, na terytorium „Nowego Świata”. Tylko tam, tylko wówczas możliwe okazało się uchwycenie znaczenia - choćby przelotnie i niejednoznacznie. Wówczas, któregoś dnia na przełomie lata i jesieni, podczas drogi powrotnej z nizin w góry, maszerując z wioski Dzembronia, mijając kolejne gospodarstwa, wspinając się na szczyt do chaty u podnóża Czarnohory, znalazłam w rzece kamień. W jego szarą strukturę wpisane były dwa białe kręgi - podwójne koło - huculski kołacz. Rok później, przebywając w granicach „Starego Świata”, natrafiłam z kolei na autolitografię z 1912 roku, przedstawiającą młodą huculską dziewczynę. Sportretowana Hucułka z początku minionego wieku ma moje rysy twarzy i posturę, jest zwierciadlanym odbiciem mojej postaci. Co więcej, dziewczyna stoi przed przełaska [ogrodzeniem - A.M.], nieopodal drewnianego budynku gospodarczego, a w tle rozpościera się krajobraz Czarnohory. Utrwalone na litografii miejsce do złudzenia przypomina gospodarstwo, w którym mieszkałam podczas prowadzonych badań. Figura powtórzenia, odbicia wydaje się rodzajem weneckiego lustra, sugerującego nieuchwytną przestrzeń „pomiędzy”, w której możliwa staje się integracja „Starego i Nowego Świata". Znalezienie kamienia, w który wrysowany jest po- 
dwójny krąg oraz obrazu, będącego moim portretem, choć sprzed wieku - te dwa zdarzenia otwierają niejednoznaczne pole, sugerując nieśmiało myśl o równoległości dwóch światów. W tym obszarze, w tym „wspólnym polu”, może dokonać się, mniemam, ostatnia faza obrzędu przejścia antropologa podczas badań terenowych - przejście z fazy liminalnej do fazy postliminalnej, akt włączenia do „Świata Zintegrowanego”. W lustrze ustawionym w progu odbijają się dwie postaci - jedna z nich zamieszkuje „obszar zewnętrzny”, druga „obszar wewnętrzny”. Obie postacie spotkały się w szczelinie „pomiędzy”.

Opisane przeze mnie doświadczenie jest realne, materialne, nie zaś wyobrażone czy odczute. $\mathrm{Z}$ nieskrywanym zdziwieniem i zaniepokojeniem wpatruję się w realnie istniejący obraz Hucułki, który jest moim odbiciem. To jedno z tych wydarzeń, które „nakazują etnografom wątpić w proste oczywistości” (s. 76-77).

Jak widać, taka mistycyzująca subiektywizacja dyskursu może skutecznie zaciemnić przekazywane treści, a nawet całkowicie ukryć je pod trudnymi do interpretacji metaforami i symbolami. Oto kolejny przykład:

Dążąc do rozpoznania tego, co mieści się na obrzędowej huculskiej skene, rozumianej jako „zakryte, niewidzialne dla oczu widza miejsce, gdzie aktorzy zakładają swe maski, miejsce, w którym to, co widzialne, istnieje w ścisłym związku z tym, co niewidzialne”, zmuszona byłam przekroczyć szereg kolejnych granic - tych fizycznych oraz tych niematerialnych. Czyniłam tak, by stać się obecną w strefie pomiędzy jednym a drugim kręgiem kulturowym, tym, co rozpoznane i nierozpoznane. Zyskałam status pielgrzyma w niekończącej się podróży. [...] Celem pielgrzymki każdego wędrowca jest poznanie. Ceną poznania jest natomiast pewna forma zatracenia oraz nieunikniona i nieodwracalna transformacja. Tak widziany, proces badań terenowych jawi się swoistym rite de passage. Podobnie jak podróż, przeobraża się w wędrówkę bez powrotu, ujawniając niejako, że nie ma go i nie może być. Ma rację Magris, gdy mówi, że podróżować nie oznacza znaleźć się po drugiej stronie granicy, lecz zrozumieć, że zawsze jest się także po tamtej stronie (s. 12-13).

W innym miejscu autorka pisze:

Oba dzieła [Dido Iwańczyk Szekeryka-Donykiwa i Na wysokiej połoninie Stanisława Vincenza - A.M.] są rodzajem żywej opowieści, która oprócz tego, że jest skarbnicą wiedzy o Huculszczyźnie ma moc wtajemniczenia odbiorcy. Odnalezienie ścieżki do tej ukrytej szczeliny-tunelu jest początkiem drogi do krainy, w której „czas spowija duszę jak stary piastun. Dziwne nasienie wylęga, sny i pieśni. Czeka i czuwa, aż dojrzeje piękno [...]. Chroni i wylęguje to, co ukryte w człowieku" (s. 63). 
Nie zaskakuje więc czytelnika fakt, że podrozdział wyrażający credo metodologiczne autorki został zatytułowany tajemniczo W metodologicznej szczelinie i że zawiera on równie zagadkowe konstatacje:

Jedno z podstawowych pytań, które sformułowałam w tamtym momencie, koncentrowało się na tym, co mieści się w szczelinie pomiędzy teatrem a życiem, [...] pomiędzy doświadczeniem i przeżyciem badacza-uczestnika a formułowaną przez niego konstrukcją teoretyczną oraz pomiędzy formą albo strukturą obrzędu przejścia a jej cielesnym wypełnieniem. Kolejne, wyprowadzone z powyższych pytanie dotyczyło tego, czy ta szczelina jest rodzajem jakiegoś ukrytego wspólnego pola? Udzielenie odpowiedzi twierdzącej musiało oznaczać i oznaczało w praktyce, niepewne, acz nieuniknione balansowanie „niczym gimnastyk na równoważni” pomiędzy tym, co zewnętrzne, a tym, co wewnętrzne, w celu rozpoznania tego, co „pomiędzy”. To, co znajduje się w szczelinie, niewidoczne jest bowiem ani z zewnątrz, ani od wewnątrz. Toteż trzeba przejść drogę między tymi dwiema przestrzeniami. Stać się chwilowo obecnym w przestrzeni „pomiędzy”, wejść w głąb, spojrzeć z wewnątrz przez szczelinę na zewnątrz, a następnie przejść droge powrotną, by spojrzeć do wewnątrz (poprzez tę samą szczelinę) z zewnątrz (s. 67-68).

W świetle powyższych przytoczeń rodzi się zasadne pytanie o stopień samoświadomości badawczej Adriany Świątek i o proporcje racjonalizmu i irracjonalizmu w jej podejściu do rzeczywistości. Jak się zdaje, znacznie więcej w recenzowanej monografii da się zaobserwować inspiracji romantyzmem niż pozytywizmem, a to musi wywoływać u czytelnika Huculskich peregrynacji weselnych uczucia ambiwalentne: z jednej strony niekłamany podziw dla erudycji, sumienności i dokładności czy wręcz drobiazgowości autorki, dokumentującej i porządkującej w czytelny sposób badane fakty kulturowe, z drugiej zaś strony niechęć do jawnie romantycznego wartościowania przemian kultury ludowej, idealizującego jej przeszłe formy, utrwalone przez poprzedników badaczki: „Niestety, coraz częściej Huculi zastępują arcydzieła rękodzielnictwa kolorowymi ceratami, które nazywają "klejankami«” (s. 95); „Zanim kobieta rozpocznie proces szycia wianka, w izbie zazwyczaj zbierają się inne kobiety. Niestety coraz rzadziej...” (s. 113). Taki negatywny stosunek do przemian tradycji, traktowanych jako godne potepienia odchodzenie od autentycznych ludowych wzorców ku formom gorszym, gdyż tandetnym i zdehumanizowanym, skłania niekiedy autorkę do manifestacji w swoim dyskursie - w co trudno uwierzyć czytelnikowi tekstu utrzymanego w konwencji wypowiedzi naukowej - myślenia otwarcie i nieskrępowanie magicznego, którego przykładem może być choćby stwierdzenie: „Dziś ludzie zapomnieli, że diabeł, czort, jak mówią Huculi, nadal mieszka we wsi i »łypie oczyma na lewo i prawo«. Może dlatego, że Huculi przestali przestrzegać procedury wypieku kołacza, coraz powszechniejsze stały się na Huculszczyźnie rozwody?” (s. 129). A że nie jest to bynajmniej żart 
badaczki, przekonuje przypis, jakim opatrzyła ona przytoczone zdanie: „W okresie 2011-2016 uczestniczyłam w dziewięciu weselach - z tych dziewięciu małżeństw trzy się rozpadły” (tamże). Trzeba zatem poważnie traktować również zapewnienie Świątek, że: „W kompozycji monografii kluczową i nieprzypadkową rolę odgrywa liczba »trzy«, posiadająca wyjątkowe znaczenie w huculskiej i w ogóle słowiańskiej kulturze ludowej” (s. 24) - dopowiedzmy, znaczenie wybitnie magiczne. Wszystko to, w połączeniu z widoczną w powyższych cytatach egzaltowaną stylistyką, każe zadumać się nad kierunkiem, w jakim zmierzają dziś nauki humanistyczne. Jeśli w dodatku w recenzowanej (jako rozprawa doktorska) przez specjalistów monografii czytamy, że cerkiew jest dziełem natury, a nie cywilizacji („Przestrzeń mistrzowsko zaprojektowana przez wybitnego scenografa - naturę, gdzie droga jest autentyczną, wyboistą i niedoskonałą drogą, rzeka prawdziwą rwącą rzeką, cerkiew - rzeczywistą świątynią - cerkwią” s. 90; „Natura sama komponuje najdoskonalsze obrazy. Bywa, że Hospod Boh pomieszkuje w niewielkiej cerkiewce na grzbiecie jakiejś góry” - s. 190), to zaiste jest nad czym rozmyślać. 